\title{
ANNUAL REPORT ON THE U.S. PROGRAM OF TECHNICAL ASSISTANCE TO SAFEGUARDS OF THE INTERNATIONAL ATOMIC ENERGY AGENCY (POTAS) JANUARY-DECEMBER 1977
}

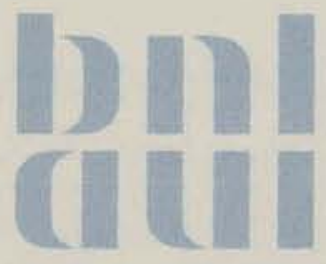

\author{
March 1, 1978
}

\section{INTERNATIONAL SAFEGUARDS PROJECT OFFICE}

BROOKHAVEN NATIONAL LABORATORY ASSOCIATED UNIVERSITIES, INC. UNDER CONTRACT NO. EY-76-C-02-0016 WITH THE UNITED STATES DEPARTMENT OF ENERGY 


\section{DISCLAIMER}

This report was prepared as an account of work sponsored by an agency of the United States Government. Neither the United States Government nor any agency Thereof, nor any of their employees, makes any warranty, express or implied, or assumes any legal liability or responsibility for the accuracy, completeness, or usefulness of any information, apparatus, product, or process disclosed, or represents that its use would not infringe privately owned rights. Reference herein to any specific commercial product, process, or service by trade name, trademark, manufacturer, or otherwise does not necessarily constitute or imply its endorsement, recommendation, or favoring by the United States Government or any agency thereof. The views and opinions of authors expressed herein do not necessarily state or reflect those of the United States Government or any agency thereof. 


\section{DISCLAIMER}

Portions of this document may be illegible in electronic image products. Images are produced from the best available original document. 


\section{ANNUAL REPORT ON THE U.S. PROGRAM OF TECHNICAL ASSISTANCE TO SAFEGUARDS OF THE INTERNATIONAL ATOMIC ENERGY AGENCY (POTAS) JANUARY-DECEMBER 1977}

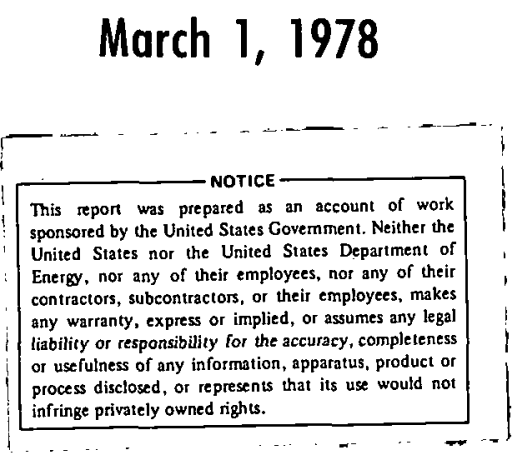

INTERNATIONAL SAFEGUARDS PROJECT OFFICE

BROOKHAVEN NATIONAL LABORATORY UPTION; NEW YORK 1.1973 
NOTICE

This report was prepared as an account of work sponsored by the United States Government. Neither the United States nor the United States Department of Energy (DOE), nor any of their employees, nor any of their contractors, subcontractors, or their employees, makes any warranty, express or implied, or assumes any legal liability or responsibility for the accuracy, completeness or usefulness of any information, apparatus, product or prucess disclosed, or represents that its use would not infringe privately owned rights.

Printed in the United States of America

$$
\text { Available from }
$$

National Technical Information Service

U.S. Department of Commerce

- $5285 \cdot$ Port Royal Road

Springfield, VA 22161

Price: Printed Copy $\$ 4.00$; Microfiche $\$ 3.00$

November 1978

400 copies 


\section{Foreword}

The U.S. Program of Technical Assistance to IAEA Safeguards (POTAS) is now entering its second year of assistance to the safeguards activities of the Internationa1 Atomic Energy Agency (IAEA). POTAS was described in the "Program Plan for Technical Assistance to IAEA Safeguards," March 25, 1977. (1) A revised program plan (March 10, 1978) has been approved and issued, reflecting the status of completed and continuing tasks and including new tasks being undertaken.

This document summarizes the work done under the U.S. Program of Technical Assistance to IAEA Safeguards, providing the U.S. Government, IAEA and others with a short review of the progress made in the program during calendar year 1977. The size and complexity of the program precludes a detailed discussion of all activities within the format of this report. Therefore, only major accomplishments are highlighted herein.

Many individuals and groups have contributed to the success of the program. Particularly helpful have been: H. E. Lyon, Director, DOE/OSS and W. C. Bartels, DOE/SS Coordinator of International Programs; the U.S. Mission to IAEA who provided the essential liaison between the U.S. and the Agency; $\mathrm{Dr}$. A. von Baeckmann of IAEA who provided a smooth interface between the technical groups in the U.S. and their counterparts at the Agency; and the Inter-Agency Steering Group and their representatives from State, DOE, ACDA and NRC.

A list of references and a list of definitions of acronyms are given on page 19 and 20 of this report. 


\section{U.S. Assistance to IAEA Safeguards}

The safeguards implemented by IAEA are of major importance to the nonproliferation objectives of the United States of America and of other nations of the world. Assurance of safeguards effectiveness is mandatory if the peaceful use of nuclear power is to be continued while these nonproliferation objectives are maintained. The U.S. makes technical assistance available to enhance the ability of the IAEA to apply safeguards effectively and to ensure that the IAEA does not lack such technical assistance as the U.S. can readily supply. The U.S. Program of Technical Assistance to Safeguards (POTAS) is the vehicle by which this assistance is supplied.

In addition to the technical-type assistance in POTAS, substantial U.S. policy-type assistance is also being provided to the. IAEA safeguards program. Policy assistance includes: efforts through the Nuclear Suppliers Group to extend the application of IAEA safeguards; development and promotion of multinational, regional fuel cycle centers including international regimes for spent fuel or plutonium storage; implementation of the U.S. offer to permit application of IAEA safeguards to all U.S. nuclear facilities except those of direct national security significance; and, perhaps most importantly, strong U.S. support for needed growth of the IAEA safeguards program.

In February 1978, the U.S. enacted the Nuclear Nonproliferation Act of 1978 which includes provision for the continuance of both technical and policy assistance to IAEA safeguards.

\section{Scope of U.S. Technical Assistance}

The POTAS contributions complement other resources available to the IAEA based on funding from its regular budget. This assistance provides reaction to identified, urgent needs to improve effectiveness more quickly than can be supplied by normal IAEA administrative procedures. Special expertise is made available to strengthen IAFA capabilities in areas where their expertise is limited. Where U.S. research has developed and tested advanced technical capabilities for safeguarding, results are made available to IAEA. Under POTAS, members of the IAEA staff are given opportunities to become experienced with actual operating conditions at nuclear facilities, conditions which they will encounter in the discharge of their safeguards duties. POTAS responds to other needs for U.S. assistance, but those outlined above have the highest urgency.

\section{Trends in IAEA Safeguards Requirements}

Currently, and for the next few..years, safeguards implementation must take three major changes into account: 
- The great increase in volume of information that must be gathered, evaluated, and analyzed as more nuclear facilities come under. IAEA safeguards.

- The implementation of IAFA safeguards at new facilities central to the success of nonproliferation efforts, including uranium enrichment plants, commercial spent fuel reprocessing plants and plants for the fabrication of mixed uranium-plutonium oxide fuel and highly enriched uranium fuel. Though the IAEA has had experience with small isolated plants of these kinds, there is little experience with international safeguards in large commercial plants.

- As the number and size of facilities under IAEA safeguards increase rapidly, the IAEA will have to deal with complete nuclear fuel cycles within single states or close international groupings of states. The current pattern of nuclear materials transfers from nuclear weapon states to non-nuclear weapon states will become less important than transfers between or within non-weapons states. The existing systems and techniques of IAEA safeguards will require adaptation, development, and testing to maintain a credible level of effectiveness under these new conditions.

\section{Summary of POTAS Contributions}

The IAEA safeguards staff is already heavily loaded by present requirements and, for the reasons stated earlier, the load will increase several fold. POTAS can help by implementing the required growth in skilled manpower to meet the immediate new requirements and by introducing new safeguards methods to decrease the effort required for each facility. A step increase in staff effectiveness is being accomplished by provision of U.S. technical experts and consultants to work as cost-free experts under individual contracts with the IAEA. Many of the tasks in the program address new technology and improvement of existing technology for nuclear assay, containment, surveillance, and seals.

The POTAS approach to improving IAEA's effectiveness and timeliness of detection is best illustrated by enumerating some of the current activities. In the area. of measurement technology, specific new tasks are being directed at developing more effective methodologies useful to the IAEA staff; simultaneously, newly available U.S. technology is being effectively transferred. Other tasks are directed at the immediate and important need for reliable, tamper-indicating surveillance equipment that will give timely indication of diversion. Cost-free experts have helped to make early and substantial improvements in systems for analysis of IAEA inspection reports. IAEA inspection exercises conducted at large U.S. nuclear facilities have proved to be highly useful in establishing precedents for inspection and reporting on a worldwide basis. Several studies are in progress to assist IAEA in developing safeguards approaches to facility types new to the IAEA. With U.S. 
technical and financial help, training of IAEA staff and officials from Member States has been continued and broadened, consistent with future plansand undertakings.

It must be recognized, of course, that safeguards requirements. will not remain static. The dynamic nature of worldwide nuclear expansion will require new future agreements between IAEA and States submitting. future facili.ties to IAEA safeguards. Consequent changes are to be expected. in IAEA safeguards functions leading to further policy and technology demands. POTAS will be prepared to respond. to these demands.

\section{Program Implementation}

Under the leadership of the President and with Congressional intiatives, the Department of. State, DOE, ACDA, and NRC each have responsibility for parts of the program of technical assistance to IAEA safeguards. State provides policy guidance, obtains funding through the Agency for International Development, and delegates implementation to DOE.: An International Safeguards Project Office (ISPO) was established by DOE at Brookhaven National Laboratory, for program implementation. In addition, DOE, ACDA, and NRC are each directly contributing programmatic and technical resources to the improvement of IAEA safeguards. All policy or technical assistance is under the cognizance of an. Interagency Steering Group, chaired by State.

DOE has substantial resources for implementing priority national programs involving nuclear technology. In expediting the technical assistance program ISPO has made full use of existing DOE laboratory resources. Participating Laboratories include Los Alamos Scientific Laboratory, Sandia Laboratories, Argonne National Laboratory, Pacific Northwest Laboratory, Brookhaven National Laboratory, Oak Ridge National Laboratory, and others. The tasks implemented at these different laboratories reflect different areas of safeguards specialization. Where needed capabilities are available elsewhere, they have been obtained under contract or IAEA has been reimbursed for procurements and contracts for special services of individuals.

\section{Organization of ISPO}

ISPO was significantly undermanned as it started implementation of the U.S. program; recruitment of additional highly qualified staff members has since met the expanding responsibilities. Starting in May 1977, a liaison office was established at the U.S. Mission to. IAEA in Vienna. The liaison post, manned full time by an ISPO staffer, provides daily contact with IAEA for quick response to questions that regularly arise in implementation of the U.S. program. Recently, ISPO has been given added responsibility in-. cluding technical management of new tasks to be implemented in the joint 
Japan-U.S.-IAEA program to test advanced safeguards instrumentation at the Tokai reprocessing plant in Japan, and responsibilities in other phases of the U.S. Initiative Program for IAEA Safeguards.

In February, 1978, the ISPO Organization consisted of:

H. Kouts, Head

L. Green, Deputy Head

C. Auerbach

J. Lemley

C. Sonnier

J. Stangby

A. Waligura

M. Rabatin, Secretary

Glen Booman of INEL accepted a BNL appointment to join ISPO in April, 1978. An additional professional is being recruited and is expected to join ISPO by June 1978 .

\section{Laboratory Program Coordinators}

Coordination between ISPO and the participating laboratories is maintained through laboratory coordinators who provide monthly reports of technical progress and financial status of the tasks assigned to their laboratory. Coordinators meet quarterly with ISPO and the Interagency Technical Support Coordinating Committee, for a review of technical progress. The Program Coordinators are:

C. Bingham - New Brunswick Laboratory

C. Hatcher - Los Alamos Scientific Laboratory

R. Heath - Idaho National Engineering Laboratory

J. Indusi - Brookhaven National Laboratory

M. Kanter - Argonne National Laboratory

$J$. Ney - SANDIA Laboratories

R. Sorenson - Battelle-Pacific Northwest Laboratory

R. Tannert - Oak Ridge National Laboratory

T. Yolken - National Bureau of Standards

\section{Program Funding}

The program as initially proposed consisted of 98 tasks based on urgent needs identified in early discussions with the Agency. Six tasks were later judged untimely and were deleted. The start of five other tasks was delayed for technical reasons.

After the initial program plan was approved on February 28, 1977, funds became available and estimates of cost were made firm. The start of eleven 
lower priority tasks was delayed in order to stay within available funds. In a11, 76 tasks were activated; 24 have been completed. DOE distributed the initial funding available for the program, $\$ 2,600,000$, as follows:

Argonne National Laboratory

Brookhaven National Laboratory TSO

Brookhaven National. Laboratory :ISPO

Battelle Northwest Laboratory

Idaho National Engineering Laboratory

Los Alamos Scientific Laboratory

Oak Ridge National Laboratory

Sandia Laboratory
$\$ 145,000$

253,000

$1,307,000$

100,000

45,000

408,000

35,000

257,000

The funding provided to ISPO included $\$ 250,000$ for project office operations at Brookhaven National Laboratory through 1977. Most of the balance was provided directly to IAEA for specified uses monitored by the U.S.

Mission to the IAEA in Vienna. Essentially all of the ISPO funding beyond the above identified $\$ 250,000$ was for procurements or contract services from commercial sources or individuals.

\section{Program Tasks}

The major task areas of the Program are directed at improving : six functions of IAEA safeguards activity:

A. Measurement Technology

B. Training .

C. Sy:stem. Studies

D. Information Processing

E. Surveillance and Containment

F. Support for Field Operations

A review of the major accomplishments in each task area follows. 
A. Measurement Technology:

This task area involves the transfer to the IAEA of the most useful of current U.S. nuclear materials measurement and verification technology and equipment. Significant progress has been made in the past year. U.S. experts, recruited by ISPO and provided cost-free to the IAEA, are serving under one-year IAEA contracts to help introduce new techniques. Other U.S. consultants were recruited and sent by ISPO to the Agency for short periods to assist on specific problems in measurement technology as identified in the first program plan. Help by expert consultants will be continued in 1978, where requested by IAEA. Non-destructive assay instruments and other devices were provided as "U.S. Gifts in Kind" to IAEA. Other instrument and devices are presently being completed and should be ready for delivery in the coming year.

\section{U.S. Experts Assigned to IAEA Staff:}

Two highly qualified experts in the field of non-destructive assay were provided under the initial program plan. David Rundquist of Science Applications, Inc., and John Foley of Los Alamos Scientific Laboratory (LASL) have been assigned to the Division of Development and Technical Support.

Rundquist provided advice and guidance to the IAEA staff concerning the assay of highly enriched uranium. With his assistance, IAEA is implementing more effective procedures for measurement and verification of this strategically important material. Because of his recognized abilities, Rundquist was subsequently offered, and has accepted, a regular appointment on the IAEA staff and is being considered by the IAEA for appointment as Section Head for Instrument Methods and Techniques.

Foley helped adapt the "High Level Neutron Coincidence Counter", to meet plutonium-bearing material measurement needs. Foley also worked with the IAEA staff in developing procedures for installing TV-surveillance systems at facilities under IAEA safeguards.

The IAEA has asked that both expert's positions be extended for an additiona 1 year.

\section{Non-Destructive Assay Instrumentation and Other Equipment:}

Three high level coincidence counters, built by LASL, are now being used by IAEA inspectors to routinely verify quantities of plutonium. Four additional units have been requested for urgent use in 211 parts of the world.

IAEA staff, attending NDA training programs at LASL, train on instruments in actual use by IAEA inspectors. To supplement the instruments already at LASL, other instruments currently in use by IAEA inspectors were procurred including four Silena manufactured Multichannel Analyzers. Four 
Beta reflectometers will be acquired this year.

Fifty pocket-type radiation monitors were purchased for use by inspectors in the field. IAEA now has a sufficient number so that each inspector can carry at least one unit. Their availability contributes to improved inspection performance by allowing each inspector to monitor his own radiation exposure.

Various other purchases were expedited: filaments for the IAEA's two-stage mass spectrometer, equipment for processing specialized film after exposure in instruments developed to monitor reactor power, specialized Cd Telluride detectors, film magazines for surveillance cameras, etc. In most cases procurement by ISPO reduced the delivery time for these specialized items by a factor of two.

3. Special Assistance in Measurement Technology:

Other U.S. experts provided assistance on special problems with measurement technology now in use or being developed by IAEA. Experts worked directly with IAEA staff so that recommendations, could be applied immediately.

Dan Lovett of General Electric/Vallecitos assisted IAEA in processing film from IAEA reactor power monitors using the "track-etch process," originally developed for ACDA. Lovett made recommendations for modifying the processing equipment, and trained and assisted the staff at the IAEA Safeguards Analytical Laboratory, Seibersdorf Austria (SAL) in the etching of exposed film from reactor power monitors. (2) Although it was possible to process most of the film, the IAEA could not make a good comparison with facility reactor power data. These tests had been conducted prior to POTAS in reactors outside the U.S. where it was not always possible for the IAEA to work closely with the reactor operator. IAEA has requested that additional tests to evaluate the technique be conducted at U.S. facilities. This activity has been included in the revised program plan.

R. Walker and others of ORNL assisted the staff at SAL by demonstration and training in the isotopic analysis of "resin bead" nuclear samples by the Agency's two-stage mass spectrometer. Application of the "Resin Bead Technique" will give IAEA capability for high precision analysis of samples small. enough that they may be safely and conveniently carried away by the inspector or sent through the mail system. Dave Smith of ORNL provided assistance by making recommendations for improved operation and maintenance of the mass spectrometer. An experienced spectroscopist, H. Mckown, on leave from ORNL, is on the regular IAEA staff at SAL providing an important link in the transfer of this technology.

Four experts, J.. Mandler, R. Helmer, E. Kilian and R. Morneau, of the Idaho National Engineering Laboratory (INEL), assisted IAEA in upgrading its capability for timely analysis of data obtained by nondestructive assay (NDA) of Pu bearing materials and spent fuel. INEL experts worked with the IAEA to develop, document, and implement a program for analysis of gamma 
spectra using an IAEA minicomputer. IAEA inspectors make regular use of portable multichannel analyzers to assay such nuclear materials in the field and wished to analyze the data on an ND-6620 computer in IAEA headquarters. INEL helped train inspectors and will continue to provide training and assist IAEA in making other improvements of procedures for application of gamma spectroscopy in the field.

IAEA inspectors do not have complete facilities for calibrating their NDA equipment. Los Alamos Scientific Laboratory (LASL) provides facilities, materials, and consultation for such calibrations. IAEA inspectors have conducted calibration activities at LASL four or five time in the past year and will continue such use in the coming year.

The IAEA is presently purchasing a vehicle of special design to carry NDA and other equipment for inspecting facilities in Europe. Bids for the vehicle are due in March 1978. M. Zucker of BNL/TSO worked closely with the IAEA to prepare the specification for the vehicle. Zucker will assist IAEA in evaluating the bids when they are received. 


\section{B. Training:}

The IAEA conducts training in two important areas: training Agency inspectors and training personnel of Member States who will interface with the IAEA's safeguards system. 'In the first area, U.S.: experts: assisted in planning IAEA courses or individual training and served as lecturers for these courses. In addition, DOE laboratories and other facilities provided specialized courses or individual training for inspectors. In the second area, U.S. experts were provided as lecturers and the U.S. made a direct contribution to the IAEA budget in support of travel of personnel from other Member States attending these courses.

\section{Training for IAEA Inspectors:}

Paul Ebel, of Allied General Nuclear Services, Barnwell, and formerly the Barnwell director of training, made recomendations to IAEA for improving the quality of its training program for inspectors. Ebel's recommendations have been compiled in a report for the Agency.. (3) A major recommendation in the report called for adding a teaching professional to the regular staff, who would be responsible for organizing the courses and for introducing modern and proven teaching techniques. Based on his experience, Ebel recommended the introduction of techniques for evaluating both the progress of students and the effectiveness of the teaching in such a course, and recommended that the present IAEA course material be converted into teaching manuals that would include appropriate feedback exercises.

Four courses in the use of NDA for safeguards inspectors were conducted by LASL in the past year. These courses were designed for the specific needs of the Agency. IAEA staff members, mainly inspectors but also key individuals from other safeguards divisions, attended the courses in groups of ten to twelve. In addition to providing funding for LASL purchase of special equipment, the U.S. provided funds for travel, per diem and registration for the IAEA staff taking part in the LASL courses. The training involved both the instruments currently being used by IAEA inspectors and those expected to be used by IAEA in the near future. Tom Canada, Director of the LASL program, consulted with the Agency in Vienna to review the content of the courses and to ascertain the need for modification of the courses to satisfy the IAEA's changing requirements.

At the request of IAEA, the following three individuals of the IAEA staff were given special individual training. A staff member of SAL visited ORNL for information on the use of the resin bead technique and training in other analytical methods for isotopic analysis of solutions; he also went to NBL/Chicago to review techniques for chemical analysis for Pu content. A member of the Section for Development of Instruments, Methods, and Techniques was given additional training at LASL in the use of the High Level Coincidence Counter and methods for assay of spent fuel. A member of the Technical Support Section spent time at SANDIA where he studied the facilities and test equipment used to maintain TV surveillance. 
2. Training Personnel of Member States:

Special assistance was provided to IAEA in funding for the travel and per diem of persons who are responsible for implementation and administration of national safeguards systems in Member States and who attend IAEA-sponsored training courses. U.S. lecturers who helped conduct some of the courses were S. Kops, DOE/Chicago Operations Office; on auditing of facility records, R.G. Page, NRC, on State Systems, and J. Jaech, Exxon, on Statistics. 
C. System Studies:

System studies were formulated to assess the effectiveness of safeguards methods and to provide guidance.for upgrading, them within the framework of present IAEA safeguards agreements with Member States. These studies should also provide information for evaluating limitations in the existing agreements and should provide guidance for an improved safeguards program under revised and new agreements:

The studies in the past year included: integral exercises, designed to examine systematically, at operating facilities, the activities that are required for application of IAEA safeguards; special short-term studies aimed at assisting the Agency in formulating safeguards approaches for the IAEA to apply at various stages of the fuel cycle; and system models, for forecasting IAEA inspection effort and assessing the impact of safeguards criteria on the Agency's requirements for manpower and resources.

\section{Integral Exercises:}

An integral exercise conducted at the GE-Wilmington fuel fabrication plant was started by DOE more than three years before the start of POTAS and will be completed in early 1978; the "Wilmington Exercise" is now a joint program with GE, IAEA, DOE and NRC. The exercise has given the IAEA and the U.S. valuable experience in the implementation of IAEA safeguards at a large nuclear fuel manufacturing facility. The study is providing guidance to IAEA in meeting its near-term and long-term objectives for safeguarding facilities in the U.S. and in other countries. The Technical Support Organization at Brookhaven (TSO) has the responsibility for coordinating the task activities and for assembling the final report. With extensive participation of all of the involved organizations, it was possible to simulate, in detail, the major activities needed for implementing IAEA safeguards. The activities included:

- Preparation of an example Design Information Questionnaire (DIQ).

- Verification of the design information.

- Preparation of an example Facility Attachment (FA).

- Design of a sampling plan to verify flow and inventory.

- Simulation of reporting (facility to NMMSS to IAEA).

- Simulation of the verification procedures that might be applied by IAEA.

The example documents, the DIQ and FA, provided the IAEA with models for use in training Agency staff and for future negotiations with member states. The two documents plus other reports generated during the exercise provide complete example documentation necessary to the application of safeguards to LEU fabrications plants. The final report is currently in draft $(4)$ and references twelve documents generated during the exercise.

Two other Integral Exercises, although more limited in scope, were concluded in the past year. Example DIQ's were provided for a LWR facility 
based on Dresden (5) and for a reprocessing facility based on AGNS/Barnwe11. (6) These exercises were also a joint effort with Commonwealth Edison Electric (for Dresden), AGNS (for Barnwel1), IAEA, DOE, and NRC participating. BNL/TSO coordinated the preparation of the example DIQ's.

\section{Special Short-Term Studies:}

A number of short-term studies were initiated this past year and have resulted in the preparation of draft reports that were circulated for comment, some of which are complete. The reports covered these subjects:

- Estimation of material flow and material on inventory at typical nuclear facilities - LASL.

- Safeguarding fast breeder reactors - ANL.

- Safeguards aspects related to heavy water - TSO assisted by a U.S. expert on heavy water production.

- Explanatory notes for preparing DIQ's for enrichment facilities - Science Aplications, Inc. (SAI).

- Diversion Analysis for LWR's and reprocessing facilities - SAI.

3. System Models:

The Agency has assembled a forecasting data base that is used to assess the growing need for safeguards manpower and other resources. The data base exists mainly in report form ("World Nuclear Activity", IAEA/STR40), is quite large and needs frequent updating. To make more efficient use of this information, IAEA asked for assistance in formulating a forecasting model, particularly one that would incorporate a computerized version of the data base. John Sanborn of BNL was assigned to the IAEA staff as a costfree expert for the task, and has completed the formulation of the forecasting model and the design of a computerized data base. Sanborn has completed the documentation; implementation of the model is forthcoming. 


\section{Information Processing:}

Because of the increase in the quantity of information being reported to IAEA by member states there has developed a need for the. rapid expansion and upgrading of the Agency.'s computer based information system. Limitations of the Agency's budget and staff would have prevented essential expansion of the system if assistance had not been provided by the U.S. support program.

The assistance provided in this task included: direct financial contribution to the IAEA to permit early acquisition of a larger computer, peripherals and software for the new system; other equipment provided as gifts-in-kind; and cost-free experts to assist IAEA in planning, system design and programming. for the upgraded safeguards system.

\section{Direct Financial Contribution:}

Experts studied the future needs of the Agency's information system and recommended immediate acquisition of a new and larger central processing unit. Since the Agency's CY 1977 budget could not accommodate any significant increase, the acquisition would have been delayed until CY 1978 . Through a direct U.S. cash contribution sufficient to pay for seven months rental, a larger computer system, IBM 370/158, was installed at the Agency in June of 1977. Rental for the new system has been carried under the regular IAEA budget since January 1, 1978.

The U.S. provided a cash contribution to IAEA to acquire two remote data terminals for rapid interaction with the new safeguards. information system. The ability for interactive access with the computer is important to analysts and programmers who are developing the new system, and to data editors and inspectors who will need access when the new system becomes operationa1: The equipment, purchased by IAEA using the U.S. contribution; consisted of two ITT Mode1 3282-3 CRT terminals, one Model 3282-1 control unit, and one Model 3282-2 printer.

U.S. contributions were also used to permit early acquisition, on a rental basis, of a Xerox 7000 reducing copying machine. Exclusive use of the copier by the Department of Safeguards has given the IAEA a costeffective way of reproducing computer printouts, particularly documents that are "Safeguards Confidential". U.S. support will cover rental cost for fiscal years 1978 and 1979 .

\section{Equipment Provided as Gifts-in-Kind:}

Two Norelco Word Processors, purchased in the U.S., were presented to IAEA for exclusive use by the Department of Safeguards. This equipment gives the IAEA capability for rapid production of typed documents and reports. Of particular interest to the IAEA is the need to type safeguards agreements that differ only a little from each other but must be produced in error-free form. The two units are now in active use, one in the Section 
for Standardization and Administrative Support and the other in the Division of Developments and Technical Support.

A Texas Instruments Silent 700 , Model 745 , a portable data terminal with dial-up capability, was purchased for the Agency. The unit will be used to test the possibility of data exchange by inspectors via telephone between the field and the computer in headquarters.

3. U.S. Experts Assigned to the IAEA staff:

Four U.S. experts, provided cost-free, are assisting in developing the new information system for safeguards. One expert, Joseph Nardi of Brookhaven National Laboratory, is serving on the IAEA for a second year. Nardi assisted in selection of ADABAS, the Agency's newly acquired data base management system, and, as Data Base Coordinator, is responsible for implementation of the system. Thomas Mills of Rockwell International, John Oakberg of Oak Ridge National Laboratory and Louis Grosman of NRC have been working on the development of the upgraded information system. Oakberg has been developing programs for pre-processing data, Mills has been designing systems for post-processing of data, and Grosman has been developing programs for report generation.

IAEA requested that three of the four experts above be extended for an additional year, to assist in completion and implementation of the new system.

Other short-term experts were provided to. assist the Department of Information Treatment in future requirements for manpower and hardware. One report was completed in draft form $(7)$ and other reports are to be completed this fiscal year. 
E. Containment and Surveillance:

This support primarily involves monitors capable of detecting the movement of nuclear materials, including surveillance systems, seals and detectors and other types of monitors. Use of such devices and techniques can increase the timeliness and sensitivity of IAEA detection of nuclear materials movement without substantial increase in inspection manpower.

Although there has been considerable progress in a number of tasks in this area, only a few have been completed in the first year of the program. Tasks scheduled for completion in the coming year include provision of improved seals, upgraded TV surveillance, and feasibility studies for applying advanced techniques to IAEA safeguards.

1. Provision of Surveillance Equipment.

A bundle counter, designed by SANDIA to be used for tests at the GE/Morris reprocessing facility, was modified at the request of the Agency. This equipment was provided to the IAEA for experiments and tests that will be conducted at the Bohunice facility in Czechoslovakia.

Three improved fiber optic seal kits were provided for Agency evaluation. The Agency arranged for Canada to help evaluate one of these kits by testing the seal on spent fuel stored in Canada.

2. Evaluation Studies:

SANDIA completed a study to assess the likelihood of applying before-the-lens-tampering techniques to TV surveillance cameras. The results of this study were given to IAEA in a special report. (8) At the request of the Agency, SANDIA has limited the distribution of the report.

SANDIA provided a special report, ISPO-4, on the expected performance of solar cells for use as gamma detectors for very high dose rates. (9) The information given to IAEA is based on work that was conducted in the DOE safeguards program. 


\section{F. Field Operations:}

Technical assistance was provided to two sections in the Department of Safeguards: the Section for Data Evaluation Services (SDES), and the Section for Safeguards Evaluation (SSE). The first section, SDES, provides mathematical and analytical services needed by the inspection divisions; procedures are developed to facilitate the collection and evaluation of inspection data on a timely basis. The second section, SSE, is a recent addition to the IAEA Department of Safeguards and has the prime responsibility for preparing the Special Safeguards Implementation Report (SSIR) wherein inspection data, collected in the previous year, are used to formulate conclusions on the effectiveness of IAEA safeguards.

U.S. assistance in Field Operations was provided in two ways: direct assistance by long-term and short-term cost-free experts, and. exchange of experience between IAEA and U.S. inspectors.

\section{U.S. Experts:}

S. Thompson, on leave from DOE, is serving as a long-term expert with the Section for Standards and Administrative Support. His prime concern is to assist in making improvements to the substance and form of agreements concluded pursuant to INFCIRC/66/ Rev 2 and. INFCIRC/153. Thompson has also taken an active part in other activities of this section. Thompson's term is for one year; the Agency has asked that he be extended for 6 more months.

Battelle Pacific Northwest Laboratory (BPNL) developed statistical methods and wrote the appropriate computer programs to permit statements on inspection results to be more quantitative. These techniques are presently being implemented by SDES. (10)

In another task, BPNL investigated the feasibility of devising an input-output method for detecting irregularities in the movement of nuclear material within a country. It was hoped that such irregularities might be indications of diversion. Although early results appeared promising, it was concluded that this kind of analysis did not have the sensitivity for providing strong, supportable conclusions. The results of this study were sumnarized in an informal report to the Agency. (11)

John Jaech of EXXON has been providing assistance in the review and editing of Part $F$ of the Agency's Safeguard Technical Manual - Statistical Procedures. Results of this work, which was initiated with ACDA funding prior to the start of POTAS, include publication of Part F, Vol. 1 of the IAEA Safeguards Technical Manual. Still to be completed and in draft is Part F, Vol. 2. Experts from laboratories in other countries also contributed to these documents.

BPNL, under ACDA funding, has been providing on-going support to IAEA in developing Isotope Correlation Techniques for safeguards 
applications. With assistance from BPNL, the Agency has developed a computerized data bank, statistical procedures for tests of significance and a procedures manual, STR-52. Under POTAS, the next step in the program will be a demonstration using actual facility data.

2. Exchange of Experience with NRC.

Arrangements were made for Gordon Hough, Section Head, SDES, to meet with the staff of Region II, NRC, and certain staff of the GE/Wilmington facility to discuss physical inventory practices at the Wilmington facility. The meeting, held at the GE facility provided IAEA with a better understanding of inspection operations performed by NRC at a LEU fabrication plant. After examining an actual physical inventory listing, Hough suggested changes in the IAEA materials code that will facilitate reporting to the IAEA from large commercial facilities of this type. A method for stratifying the inventory listing by material type and locations was developed to facilitate the formulation of sampling plans by IAEA inspectors. The results of this information exchange are summarized in an ISPO report. (12)

Agency inspectors had two opportunities for direct exchange of experience with NRC Safeguards Inspectors. In the first instance, three IAEA inspectors accompanied NRC on an actual inspection at the Westinghouse Cheswick facility. The Cheswick inspection included an inventory verification and an export shipment verification. In the second exercise, IAEA inspectors went with NRC to inspect the Texas Instrument facility at Attleburo, Massachusetts. Both facilities are under the jurisdiction of Region I, NRC. At meetings prior to the plant visit, NRC inspectors reviewed:. the inspection practices of NRC and discussed how such practices might impact, and perhaps complement, verification by the IAEA. IAEA inspectors had an opportunity to see the Region I Van which facilitates use of nondestructive assay for the purpose of verification.

M. Zucker, BNL expert in NDA, accompanied the Region I inspectors on the first visit and explained the non-destructive measurements that are being used by NRC, particularly the recently developed technique for measurement of fuel rods: 


\section{References}

1. Program Plan for Technical Assistance to IAEA Safeguards, ISPO, Brookhaven National Laboratory, March 25, 1977.

2. Track Etch Technique, Processing and Readout of Tapes, Consultation and Training, D.B. Lovett, ISPO 2, General Electric Vallecitos Nuclear Center, (NEDG 12682) (IN DRAFT).

3. Planning of Safeguards Training, P.E. Ebel, Allied General Nuclear Services, ISPO, NMS-11 (IN DRAFT).

4. Final Report, Task C.3, Integral Exercise, LEU Fuel Fabrication Faci1ity. A.M. Bieber, TSO, Brookhaven National Laboratory (IN DRAFT).

5. Design Information Questionaire for a Model Power Reactor, Task C.2, TSO, Brookhaven National Laboratory, October 1976 (Revised May, 1977).

6. Design Information Questionaire, Task C.4, Integral Exercise Reprocessing Facility, ISPO 3, S.C. Suda and A.M. Bieber, TSO, Brookhaven National Laboratory (IN DRAFT).

7. Report on a Study of Staffing Required to Complete the Development of a New IAEA Safeguards Information System, F.J. Fontana, Burndy Corp., E.M. Kidd, Union Carbide Corporation, Nuclear Division, ISPO 11, October 1977 (IN DRAFT).

8. Final Report, Task E.7, Study of.Before the Lens Tamper Detection for Camera and TV Surveillance Systems. Informal report, January 1978.

9. Results of Tests To Determine Response of Solar Cell Detector "C" to High Dose Gamma Radiation, Informal Report, June 23, 1977.

10. Fina1 Report, Task F.3, Statistical Programs for. Analyzing PAFEX. InterLaboratory Test Data, ISPO 10, K.B. Stewart, Battelle, December 1977.

11. Final Letter Report, Task F.5, Evaluation of Input Output Analysis for Safeguards, J.A. Merril1, Battelle, August 1977.

12. Final Report, Task F.7, Cooperative Study with NRC at GE Wilmington, A.M. Bieber, TSO, Brookhaven National Laboratory, March 1977 (IN DRAFT). 


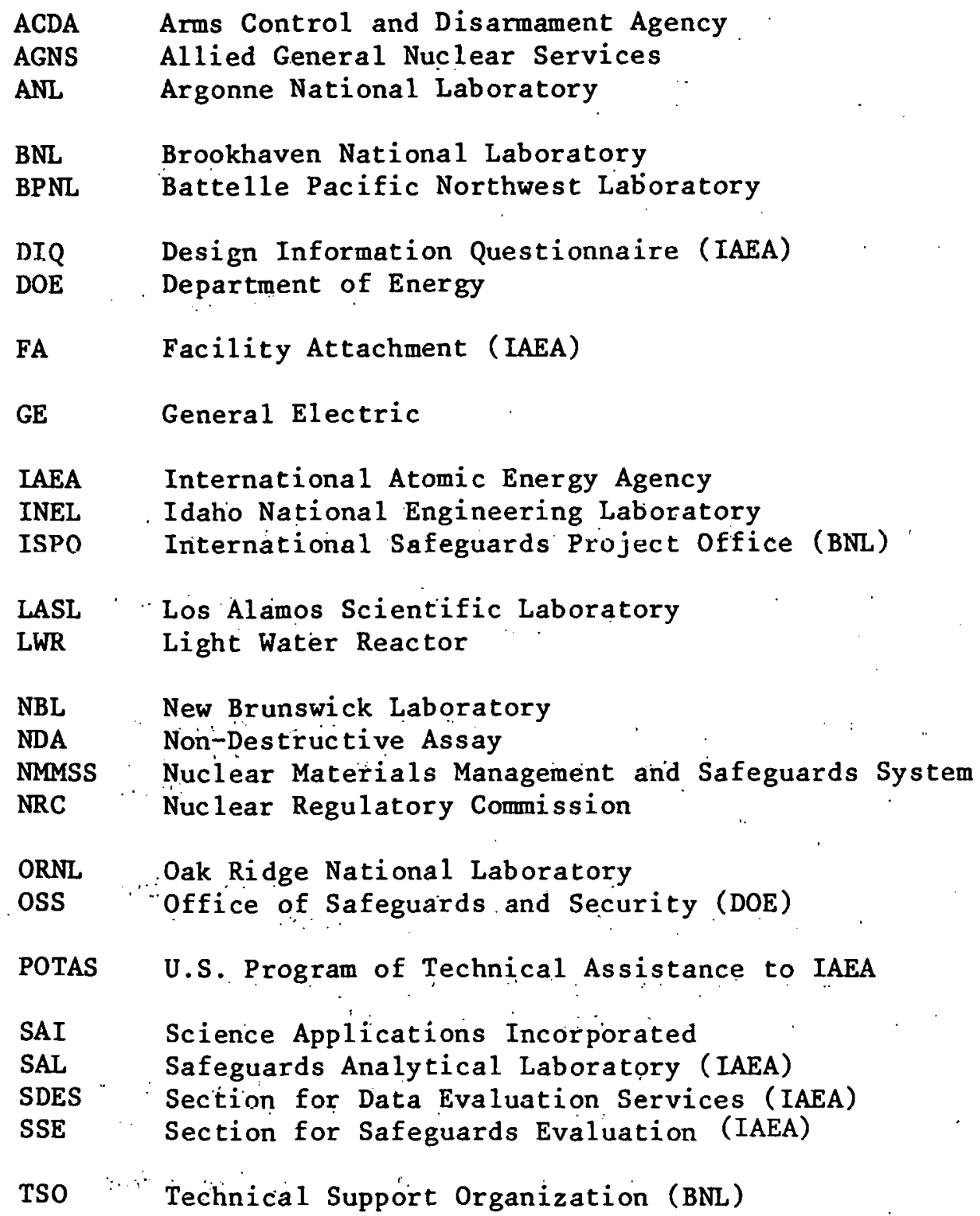


, 